\title{
Molecular Mechanisms of Functional Adrenocortical Adenoma and Carcinoma: Genetic Characterization and Intracellular Signaling Pathway
}

\author{
Hiroki Shimada ${ }^{1}$, Yuto Yamazaki ${ }^{2}$, Akira Sugawara ${ }^{3}$, Hironobu Sasano ${ }^{2}$ and Yasuhiro Nakamura ${ }^{1, *}$ \\ 1 Division of Pathology, Faculty of Medicine, Tohoku Medical and Pharmaceutical University, \\ 1-15-1 Fukumuro, Miyagino-ku, Sendai 983-8536, Miyagi, Japan; shimadahis@tohoku-mpu.ac.jp \\ 2 Department of Pathology, Tohoku University Graduate School of Medicine, 2-1 Seiryo-machi, Aoba-ku, \\ Sendai 980-8575, Miyagi, Japan; y.yamazaki@patholo2.med.tohoku.ac.jp (Y.Y.); \\ hsasano@patholo2.med.tohoku.ac.jp (H.S.) \\ 3 Department of Molecular Endocrinology, Tohoku University Graduate School of Medicine, 2-1 Seiryo-machi, \\ Aoba-ku, Sendai 980-8575, Miyagi, Japan; akiras2i@med.tohoku.ac.jp \\ * Correspondence: yasu-naka@tohoku-mpu.ac.jp; Tel.: +81-22-290-8731
}

check for updates

Citation: Shimada, H.; Yamazaki, Y.; Sugawara, A.; Sasano, H.; Nakamura,

Y. Molecular Mechanisms of

Functional Adrenocortical Adenoma and Carcinoma: Genetic

Characterization and Intracellular Signaling Pathway. Biomedicines 2021, 9, 892. https://doi.org/10.3390/ biomedicines 9080892

Academic Editor: Veronique Baud

Received: 5 July 2021

Accepted: 22 July 2021

Published: 26 July 2021

Publisher's Note: MDPI stays neutral with regard to jurisdictional claims in published maps and institutional affiliations.

Copyright: (C) 2021 by the authors Licensee MDPI, Basel, Switzerland. This article is an open access article distributed under the terms and conditions of the Creative Commons Attribution (CC BY) license (https:// creativecommons.org/licenses/by/ $4.0 /)$

\begin{abstract}
The adrenal cortex produces steroid hormones as adrenocortical hormones in the body, secreting mineralocorticoids, glucocorticoids, and adrenal androgens, which are all considered essential for life. Adrenocortical tumors harbor divergent hormonal activity, frequently with steroid excess, and disrupt homeostasis of the body. Aldosterone-producing adenomas (APAs) cause primary aldosteronism (PA), and cortisol-producing adenomas (CPAs) are the primary cause of Cushing's syndrome. In addition, adrenocortical carcinoma (ACC) is a highly malignant cancer harboring poor prognosis. Various genetic abnormalities have been reported, which are associated with possible pathogenesis by the alteration of intracellular signaling and activation of transcription factors. In particular, somatic mutations in APAs have been detected in genes encoding membrane proteins, especially ion channels, resulting in hypersecretion of aldosterone due to activation of intracellular calcium signaling. In addition, somatic mutations have been detected in those encoding cAMP-PKA signaling-related factors, resulting in hypersecretion of cortisol due to its driven status in CPAs. In ACC, mutations in tumor suppressor genes and Wnt- $\beta$-catenin signaling-related factors have been implicated in its pathogenesis. In this article, we review recent findings on the genetic characteristics and regulation of intracellular signaling and transcription factors in individual tumors.
\end{abstract}

Keywords: aldosterone-producing adenoma (APA); cortisol-producing adenoma (CPA); adrenocortical carcinoma (ACC); gene mutation; transcription factors

\section{Introduction}

Adrenocortical tumors are broadly classified into adenomas and carcinomas based on their potential biological behavior. In addition, adrenocortical adenomas are further subdivided into functional adenomas that secrete excessive steroid hormones and nonfunctional ones which do not. In this review article, we will review the findings of recently reported studies on genetic alterations and their regulation of intracellular signaling in aldosterone-producing adenoma (APA) as a cause of primary aldosteronism (PA) and cortisol-producing adenoma (CPA) as a cause of Cushing's syndrome, subclinical Cushing's syndrome, and adrenocortical carcinoma (ACC). APA is an adenoma producing excessive aldosterone autonomously, and somatic mutations of ion channels located at the cell membrane have been frequently reported, resulting in alteration of calcium signaling and its downstream transcription factors [1-5]. CPA is an autonomous cortisol-producing adenoma in which somatic mutations in genes encoding those involved in intracellular cAMP-PKA signaling [6-15] have been reported to be associated with their pathogenesis. ACC is a highly malignant cancer originating from the adrenal cortex, and mutations in 
tumor suppressor genes [16-18], those involved in Wnt- $\beta$-catenin signaling [19-21], and chromatin remodeling factors $[19,20]$ have been reported to contribute to its pathogenesis. In addition, transcription factors have been also reported to regulate the expression of downstream genes by binding to other chromatin-related proteins and epigenomic regulators to form transcription factor complexes. We will also review the relationship between gene mutations and their regulation of transcription factors, as well as the association of transcription factor complex formation in APA, CPA, and ACC.

\section{The Pathogenesis and Molecular Mechanisms of Aldosterone Overproduction in Aldosterone-Producing Adenoma (APA)}

Somatic mutations in KCNJ5, ATP1A1, ATP2B3, CACNA1D, CACNA1H, CLCN2, and CTNNB1 genes have been frequently detected in APA [1-3,22-25]. KCNJ5 encodes a rectifying potassium ion channel (Kir 3.4) that regulates resting cellular membrane potential. The genetic variants and hot spots of somatic mutations in KCNJ5 are well characterized, including L168R, G151R, T158A, G151E, I157del, T152C, and E154Q [26,27]. All of these somatic mutations can occur at ion-selective sites and cause loss of ion selectivity, leading to persistent depolarization due to sodium ions influx into the cell. The depolarization of cells enhances intracellular calcium signaling, which induces the expression of CYP11B2, one of the rate-limiting enzymes in aldosterone synthesis (Figure 1). CYP11B2 expression is mediated by orphan nuclear receptors such as $N R 4 A 1$ (NGFIB), NR4A2 (NURR1), and NR4A3 (NOR1) [28,29] and the activation of calcium signaling via CaM-CaMK $[27,30]$. It has also been reported that overexpression of mutant KCNJ5 in cell line experiments increased intracellular calcium ion concentration due to depolarization, enhanced expression of NURR1, and induced expression of CYP11B2 [31]. These results suggest that the hypersecretion of aldosterone caused by the KCNJ5 mutation is mediated by the activation of NR4A family orphan receptors via calcium signaling through the increase in intracellular calcium ion concentration, which in turn induces the expression of aldosterone synthesis genes, including CYP11B2 (Figure 2).

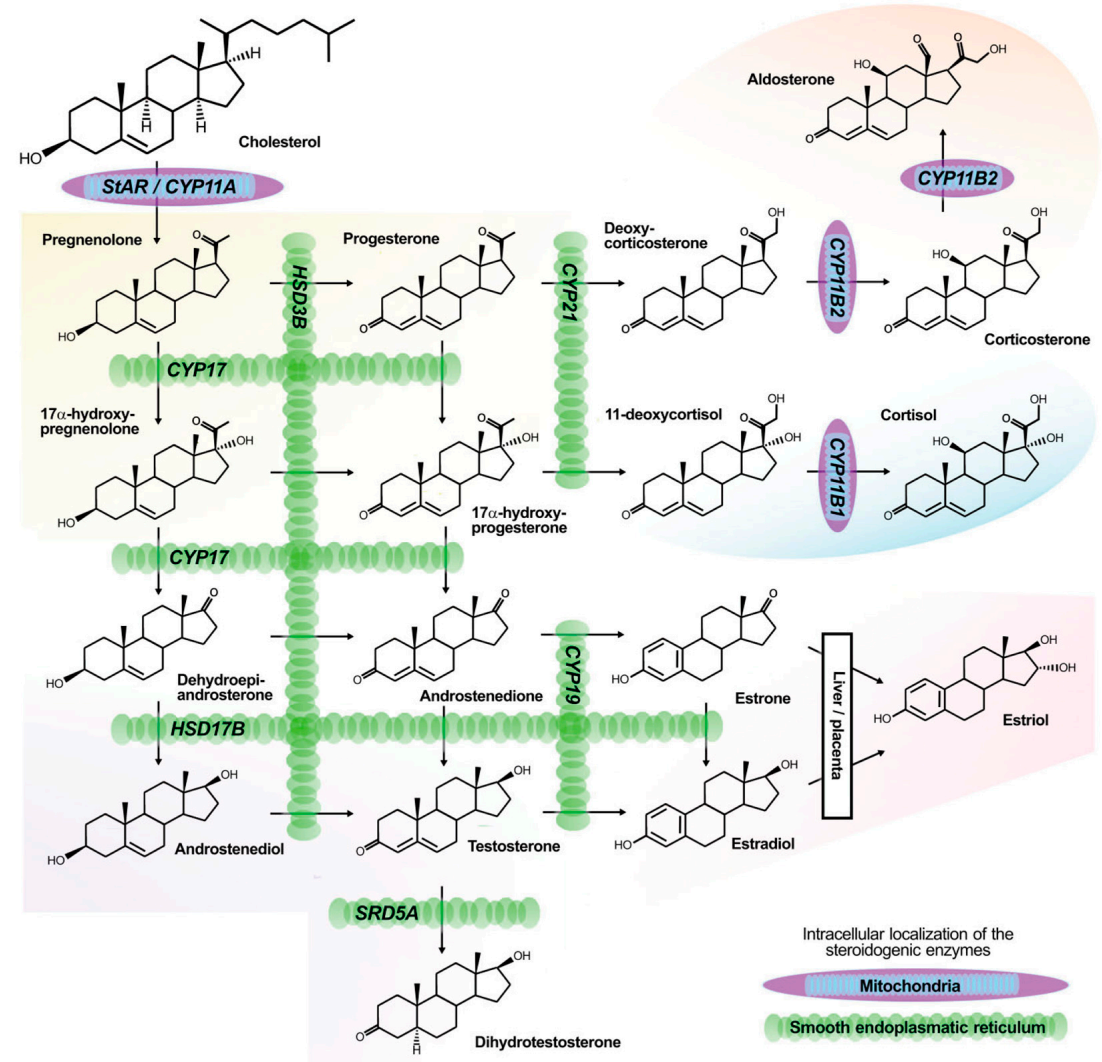

Figure 1. The steroidogenic pathways and their involved enzymes and products [32]. 


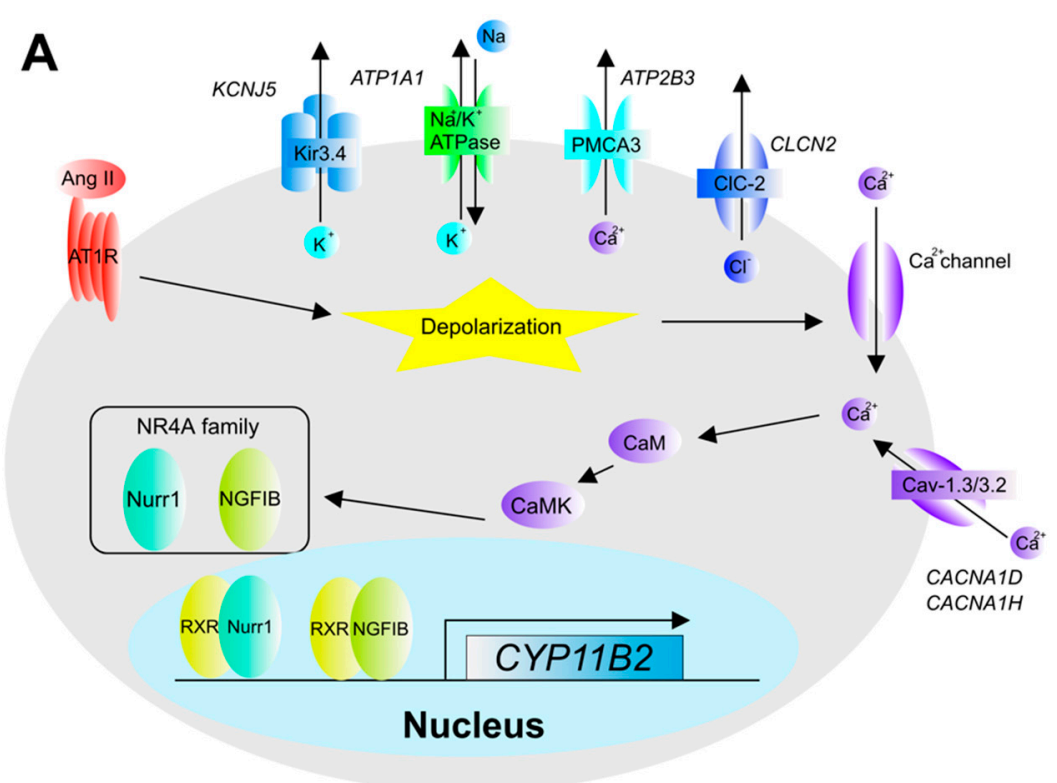

B

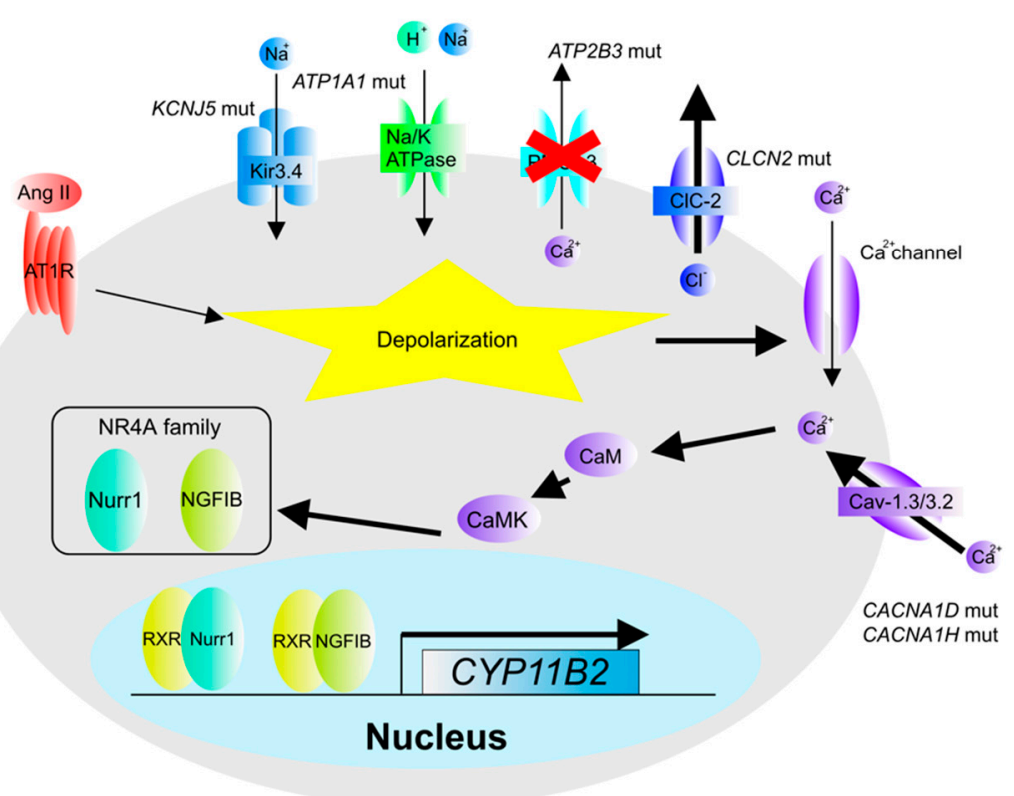

Figure 2. Gene mutations of membrane protein in APA. Depolarization of the plasma membrane is the common consequence in this mechanism. (A) Normal adrenal membrane proteins. (B) Gene mutation in adrenal membrane proteins. KCNJ5 mutation causes inflow of sodium ion; ATP1A1 mutation causes hydrogen and sodium ion leak; ATP2B3 mutation causes impaired calcium ion release; CLCN2 mutation causes impaired chloride ion release; and calcium ion influx is due to mutations in CACNA1D and CACNA1H.

ATP1A1 encodes a sodium-potassium cotransporter (sodium/potassium-transporting ATPase subunit alpha-1), a protein whose essential function is to export sodium ions out of the cell and transport potassium ions into the cells. Genetic variants of somatic mutations in ATP1A1 include L104R, del100_104,V332G, and G99R [2,22,33]. ATP1A1 L104R loses ion selectivity and allows hydrogen ions to enter the cell, resulting in an increase in aldosterone production via cell depolarization or intracellular acidification [34]. ATP1A1 del100_104 is another genetic variant that causes loss of ion selectivity, and it has been reported that the influx of sodium ions, due to the loss of ion selectivity, causes cell depolarization (Figure 2). 
The ATP2B3 gene [2,33] encodes a calcium transporter that consumes ATP and removes calcium from cells. L425_V426del and V426_V427del are the major genetic variants of somatic mutations detected in ATP2B3 genes, which cause the deletion of amino acids in the calcium ion-exporting subunit, resulting in the loss of intracellular calcium ion export. As a result, the increased intracellular calcium ion concentration induces depolarization and activation of calcium signaling, which promotes the expression of genes involved in aldosterone synthesis (Figure 2).

CACNA1D encodes an L-type calcium ion channel (CaV1.3), and somatic mutations such as G403R, S652L, F747L, and R990H have been reported [3,35-37], while G403R, S652L, F747L, and $\mathrm{R} 900 \mathrm{H}$ mutations change calcium ion gating, and these phenotypes are a gainof-function in calcium channels. CACNA1H encodes a T-type calcium ion channel (CaV3.2), and somatic mutations such as I1430T and T4289C have been reported [1]. Mutations in CACNA1H lead to gain-of-function, which is a decrease in the threshold of the potential for calcium ion influx into the cell, increasing intracellular calcium ion concentration, subsequently triggering depolarization and promoting aldosterone secretion (Figure 2).

CLCN2 is a gene coding for chloride ion channels, and somatic mutations such as G24D, 64-2-74del, and R172G have been reported [4,5,25,38]. CLCN2 has the ability to efflux chloride ions from cells. The CLCN2 gene mutation increases the ability of CLCN2 to efflux chloride ions out of the cell and induces depolarization by disrupting the ion gradient in and out of the cell (Figure 2).

CTNNB1 is a transcription factor involved in Wnt- $\beta$-catenin signaling and encodes $\beta$-catenin. Somatic mutations in CTNNB1 are detected not only in adenomas but also in ACC [18]. $\beta$-catenin is constantly degraded by phosphorylation. Inhibition of $\beta$-catenin phosphorylation prevents its degradation, resulting in its migration and activity as a transcription factor. Somatic mutations such as S33C, S45F, and S45P, which correspond to the phosphorylation sites of $\beta$-catenin, are the major variants $[39,40]$. Recently, it has been suggested that $\beta$-catenin induces the expression of NR4A family proteins and is involved in CYP11B2 gene expression. This suggests that the increased transcriptional activity of $\beta$-catenin may also contribute to aldosterone oversecretion (Figure 3).

The expression of CYP11B2 and HSD3B genes is upregulated in APA, and calcium signaling plays a major role in CYP11B2 gene expression. In addition to the driver gene somatic mutations mentioned above, various molecules that promote aldosterone biosynthesis and could contribute to the possible pathogenesis of PA have also been reported. There are also reports on the correlation between PA and factors that regulate intracellular calcium ion concentration [41]. TASK is a potassium channel whose function is attenuated by acidic extracellular conditions and the activation of Gq-coupled receptors. TASK is also highly expressed in the adrenal cortex, and TASK1 and Task1/Task3-deficient mice are particularly susceptible to depolarization of the adrenal cortex. TASK1 and Task1/Task3 deficient mice have been reported as in vivo models of PA, based on their findings of induction of depolarization in the adrenal cortex [42]. PCP4 is a protein that promotes the binding and dissociation of $\mathrm{CaM}$ and calcium ions, which are components of calcium signaling. It has been reported that PCP4 is highly expressed in APA, and because PCP4 KD reduces the gene expression of CYP11B2 [43], it may be a factor that regulates the gene expression of CYP11B2. Calneuron1 is a calcium-binding protein that transports cytosolic calcium ions to the endoplasmic reticulum (ER), suggesting its roles in promoting Ca ion accumulation in the ER. Calneuron1 is also reported to be highly expressed in APA [44], suggesting that it is also an important factor in APA (Figure 4).

$H S D 3 B 2$ was more highly expressed in the adrenal cortex than HSD3B1. However, HSD3B2 expression was not significantly increased in normal tissues and APA. In contrast, HSD3B1 is significantly upregulated in APA tissues compared to the normal adrenal cortex, suggesting that HSD3B1 is an important factor in APA [45]. Gene expression of HSD3B1 is also dependent on calcium signaling and increases in response to the transcriptional activity of the NR4A family of transcription factors, which are considered downstream 
transcription factors of calcium signaling. Therefore, the above calcium signal regulators may be involved in the gene expression of CYP11B2 as well as HSD3B1.

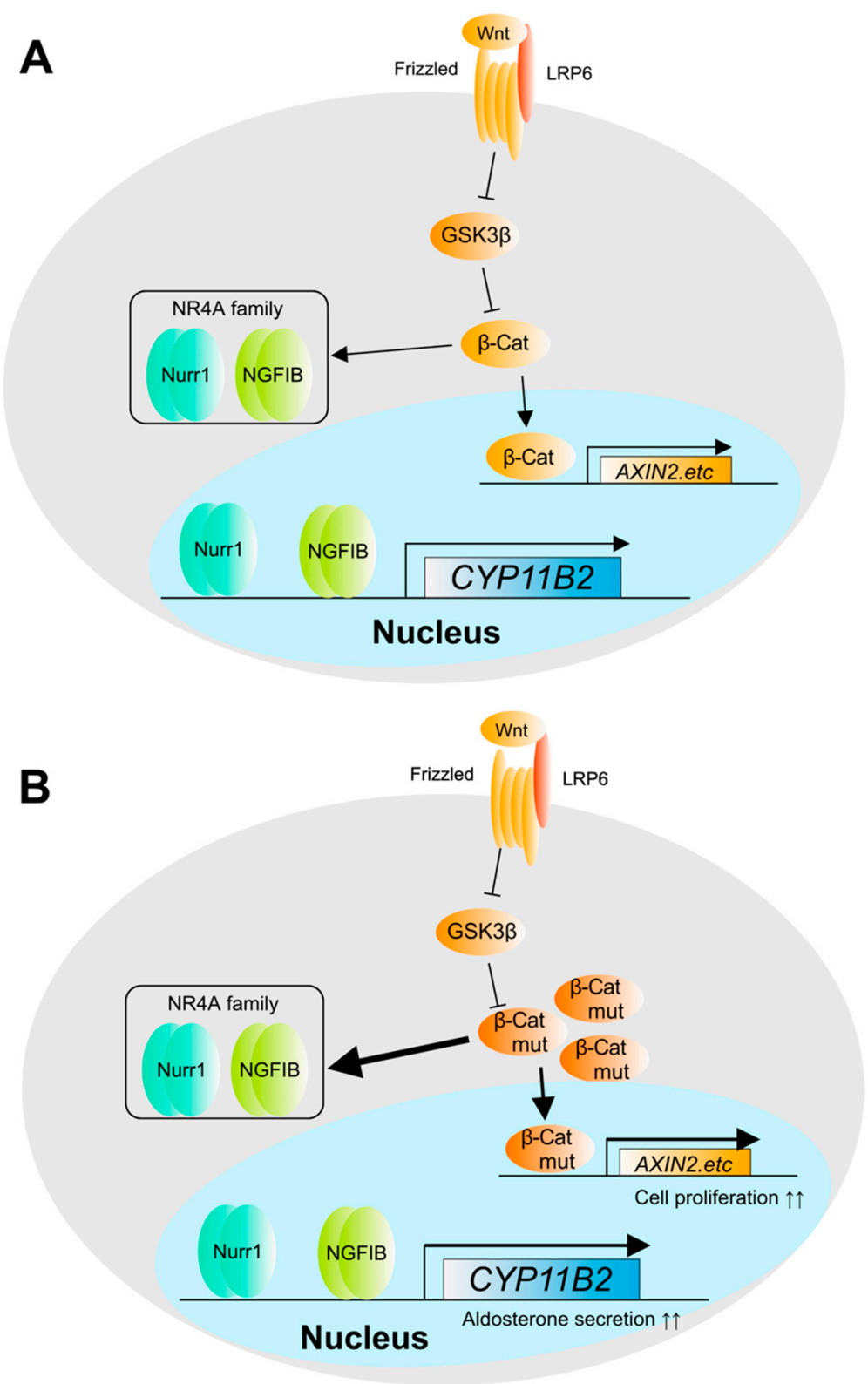

Figure 3. Mutation of CTNNB1 gene in APA. Mutations in $\beta$-catenin have been reported to activate the pathway independent from cell membrane depolarization in APA. (A) Normal adrenal $\beta$-catenin pathway. (B) Gene mutation in adrenal $\beta$-catenin pathway. $\beta$-catenin accumulates intracellularly when Wnt binds to Frizzled and induces the expression of downstream genes. $\beta$-catenin mutations cause Wnt-independent accumulation of $\beta$-catenin without degradation. Mutations in $\beta$-catenin cause it to accumulate in a Wnt-independent manner. As a result, it induces cell proliferation by activating downstream genes including AXIN2 and other cell proliferation-related genes. AXIN2 is $\beta$-catenin regulator via GSK3B. On the other hand, it has been suggested that $\beta$-catenin induces the expression of NR4A family proteins and affects CYP11B2 gene expression. 


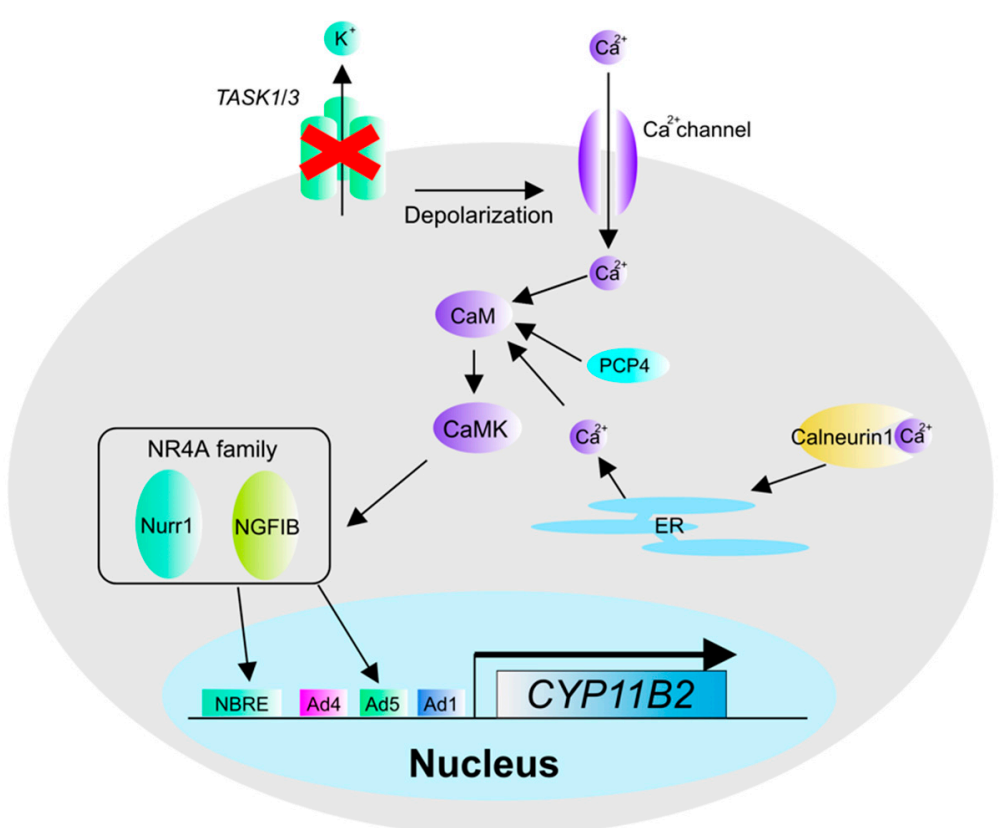

Figure 4. Calcium signaling-related factors in APA. Calcium signaling-related factors that have been implicated in the pathogenesis of APA include the potassium channels TASK, PCP4, and Calneurin1. TASK is functionally defective due to genetic mutations that cause depolarization. PCP4 is a factor that activates CaM function. Calneurin1 is a protein that binds intracellular calcium ions and transports them to the ER, where they enhance calcium signaling during depolarization.

The promoter region of the CYP11B2 gene contains transcription factor-binding sequences, such as the NGFI-B response element (NBRE), Ad4, Ad5, and Ad1. The NR4A family is an orphan nuclear receptor for which no ligand has been identified, and its expression levels and intracellular signaling may contribute to the expression of downstream genes $[28,46,47]$. The NR4A family is known to regulate the expression of downstream genes in response to their expression levels and intracellular signals. The exposure of H295R cells, a human ACC-derived cell line, to hyperglycemic conditions was reported to induce the expression of NURR1, a member of the NR4A family of transcription factors, and CYP11B2 [48]. It is known that transcription factors interact with transcription factor complexes, a group of proteins that alter the epigenomic status of chromatin to regulate the transcription of target genes. NGFIB interacts with RXR, a heterodimer partner, as well as with p300 [49], SRC-1 [50], and other histone modification factors and regulates the expression of downstream genes. NURR1 is known to interact with RXR and SRC-1 [51] as well as NGFIB. However, there are few reports on the analysis of transcriptional activation complexes in the adrenal gland for both NGFIB and NURR1, and the details of transcription factor complexes that may affect gene expression, such as CYP11B2, still remain unknown. In 2018, we identified poly (ADP-ribose) polymerase 1 (PARP1) as a transcription factor complex of NURR1 in H295R cells [52] (Figure 5). This is an in vitro study, but it could contribute to our understanding of the unknown transcription factor complex of NURR1. SF-1 has been identified as a transcription factor that binds to the Ad4 region, also known as $A d 4 B P$, and is known to be essential for adrenal and gonadal development. SF-1 expression is also reported to be upregulated in APA [53], suggesting that it affects aldosterone synthesis in APA. SF-1 has been reported to be involved in steroid synthesis. Recently, it was reported that SF-1 regulates not only the expression of steroid synthase but also the expression of glycolytic enzymes [54] and cholesterol synthase [55]. COUP-TF is a transcription factor that binds to the Ad5 region and represses the transcriptional activity of CYP11B2 in the adrenal cortex. Recently, it has been reported that COUP-TF contributes to the repression of transcriptional activity by interacting with Ubc9, a SUMO-transferase [56]. 

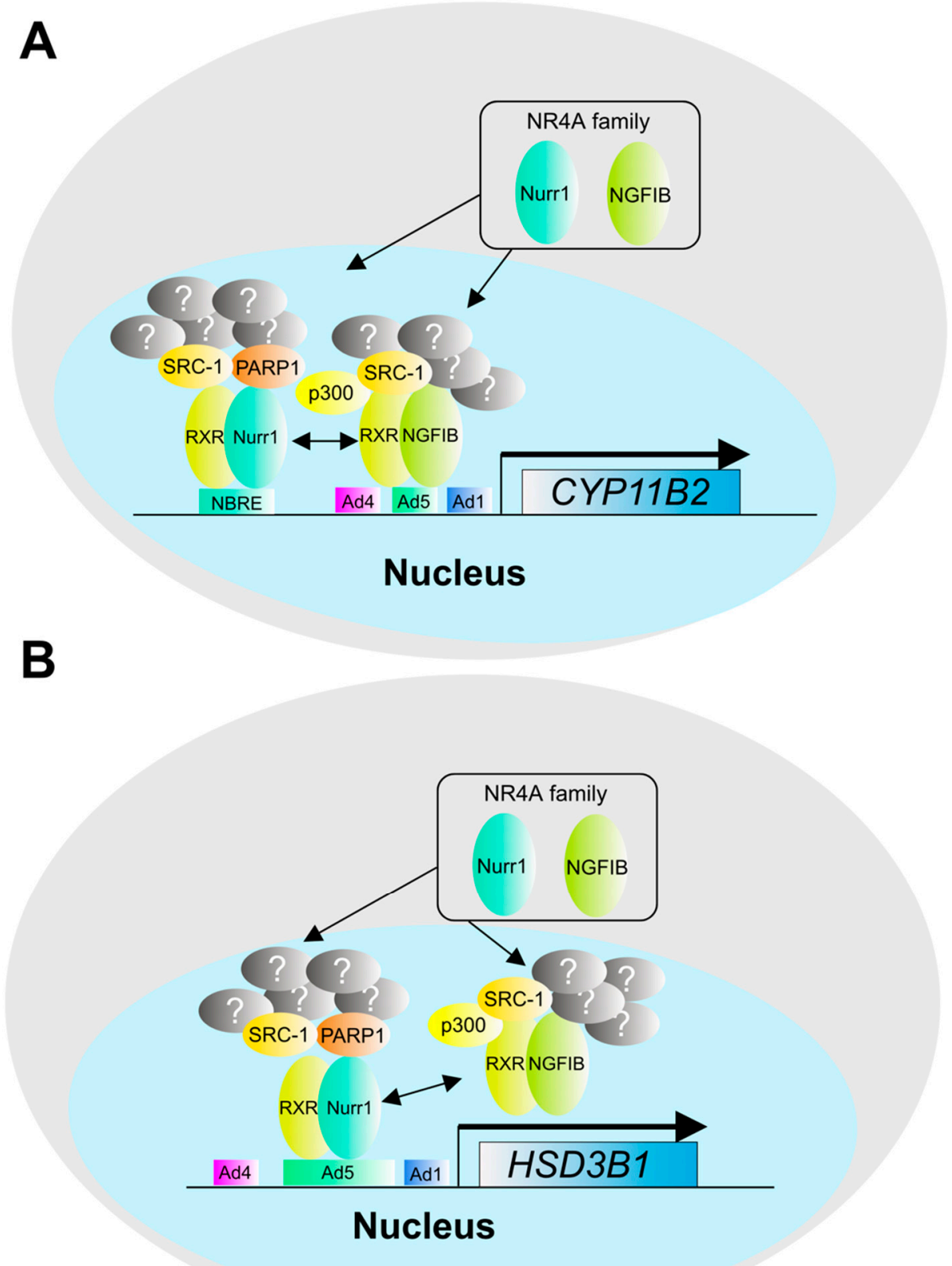

Figure 5. Transcriptional regulation of steroidogenic genes by the NR4A family. The promoter regions of CYP11B2 and HSD3B1 contain NR4A family binding sequences such as NGFIB and Nurr1, which regulate gene expression of CYP11B2 and HSD3B1 by forming a transcription factor complex. (A) Gene expression of CYP11B2 by NR4A family. (B) Gene expression of HSD3B1 by NR4A family. Although p300, SRC-1, and PARP1 have been reported as components of the complex, other components are still unknown.

On the other hand, there are few reports on the expression level of APA, and the relationship with steroidogenesis awaits further investigation. The promoter regions of the HSD3B1 and HSD3B2 genes also contain NBRE, Ad4, Ad5, and Ad1 as transcription factor binding sequences $[45,57]$. The promoter regions of the HSD3B1 and HSD3B2 genes also contain NBREs, suggesting that transcription is regulated by the NR4A family of transcription factors.

In addition, new therapeutic agents have recently been investigated. In particular, macrolide antibiotics have been suggested to inhibit aldosterone secretion by suppressing 
the function of KCNJ5 mutations [58]. It has been suggested that macrolide antibiotics inhibit cell-autonomous depolarization by binding to mutated KCNJ5 and preventing the influx of sodium ions into the cell. Similarly, for treating APA, it is thought that downregulating the expression of HSD3B1, one of the genes in the aldosterone synthesis system, and CYP11B2, the rate-limiting enzyme in aldosterone synthesis, suppresses excessive aldosterone secretion. HSD3B1 gene expression is induced by orphan nuclear receptors such as NGFIB, NURR1, and NOR1 [45,57]. NGFIB, NURR1, NOR1, COUP-TF, $\mathrm{SF}-1$, and $\mathrm{CAMP}$-response element-binding protein (CREB) are transcription factors that induce CYP11B2 gene expression [28,47].

Among them, NURR1 is a nuclear receptor whose expression increases when the intracellular calcium concentration transcriptional activity increases. NURR1 also interacts with PARP1 to regulate the transcriptional activity of target genes [52]. In vitro, it has been reported that inhibitors of PARP1 suppress aldosterone secretion by suppressing the expression of HSD3B1 and CYP11B2 [52]. In addition, bortezomib was reported to decrease CYP11B2 gene expression by altering the epigenomic state upstream of the CYP11B2 gene [59]. In addition, the drug-induced activation of other nuclear receptors, such as PPAR $\gamma$ and RXR with ligands, was reported to decrease CYP11B2 expression via NR4A family transcription factors such as NURR1 [60,61]. Although there are still many unanswered questions on potential nuclear receptor crosstalk, this is an interesting finding regarding the role of nuclear receptors in the adrenal cortex. There are also reports of compounds that inhibit aldosterone secretion by directly inhibiting the enzymatic activity of CYP11B2. Reports on the treatment of APA have focused on the development of drugs targeting the driver genes involved in aldosterone excess in APA, such as KCNJ5, as well as on the gene expression and enzyme activity of CYP11B2 and other enzymes in the aldosterone synthesis system.

\section{The Pathogenesis and Molecular Mechanisms of Cortisol Production in Cortisol-Producing Adenoma (CPA)}

CPAs, which secrete cortisol autonomously, cause Cushing's syndrome and subclinical Cushing's syndrome. Recently, CPA has been reported to be caused by somatic mutations of cAMP-PKA signaling factors, such as PRKACA, PRKACB, PRKAR1A, and PRKAR1B mutations $[6,14,62]$, as well as genetic mutations in cAMP-degrading enzymes such as PDE8B and PDE11A [11,12] (Figure 6). In addition, GNAS mutations that enhance MC2R function are also causative mutations in CPA [63].

PRKACA and PRKACB both constitute the enzymatically active subunits of PKA, and their mutations cause direct changes in the enzymatic activity of PKA $[6,14,15,62]$. PRKACA mutations were also reported in L206R and L199_C200insW, while PRKACB mutations were reported in S54L. Both genetic mutations also inhibit the recruitment of regulatory subunits and increase the kinase activity of PKA, which results in increased gene expression of CYP11B1 and increased secretion of cortisol. Recently, gene expression profiling of PRKACA-mutated CPA has been performed by RNA-seq analysis, and it is expected to reveal the whole picture of gene expression in PRKACA-mutated CPA [64].

PRKAR1A encodes the regulatory subunit $1 \alpha$ of PKA, and PRKAR1B encodes the regulatory subunit $1 \beta$ of PKA, which has two subunits: a catalytic subunit that has enzymatic activity and a regulatory subunit that controls enzymatic activity. Loss-of-function mutations in the regulatory subunit increase the enzymatic activity of PKA and activate PKA signaling. The activation of PKA signaling in the adrenal cortex induces the expression of CYP11B1, which promotes cortisol secretion, suggesting that the loss of function of the regulatory subunit of PKA is associated with the hypersecretion of cortisol. p.I40V, p.A67V, p.A300T, and other mutations in PRKAR1B have been reported [7]. p.A300T and p.A67V are reported mutations that decrease the activity of PKA [65], which is contradictory considering that PKA activation increases the gene expression of CYP11B1, but further studies are required for clarification. 

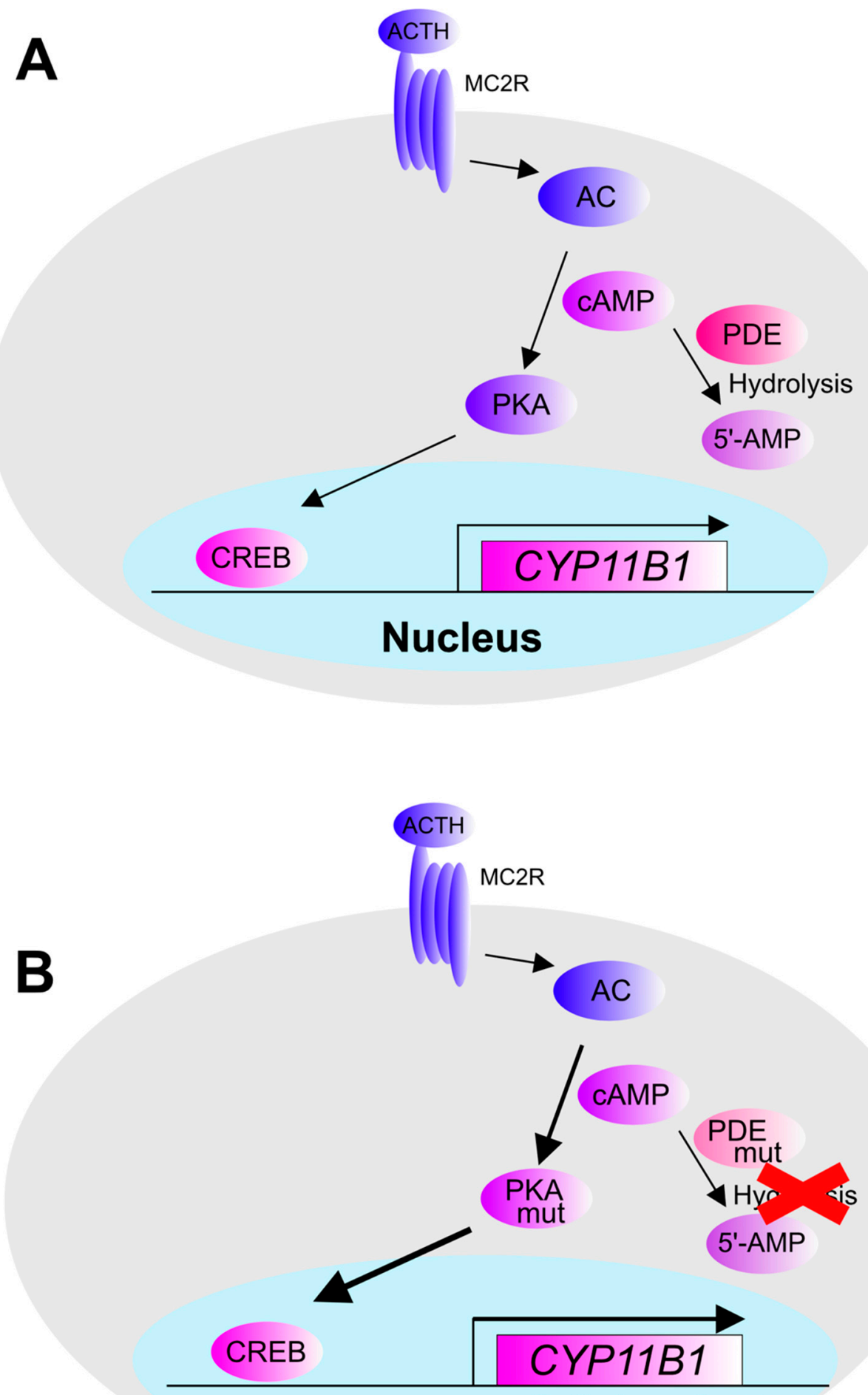

Nucleus Cortisol secretion $\uparrow$

Figure 6. Genetic mutation in CPA. Cortisol is secreted by inducing the gene expression of CYP11B1, and ACTH activates cAMP-PKA signaling by binding to MC2R of ZF cells, inducing the gene expression of CYP11B1. (A) Normal adrenal CAMP-PKA pathway. (B) Gene mutation in adrenal cAMP-PKA pathway. In CPA, mutations in PRKAR1B, PRKACA, and $P R K A C B$, which are subunit genes of PKA, and mutations in PDE8B and PDE11A, which are enzymes that degrade cAMP, have been reported. 
In contrast, phosphodiesterase (PDE) family proteins, to which PDE8B and PDE11A belong, function as cAMP-degrading enzymes. When intracellular cAMP is degraded by PDE family proteins, PKA decreases its enzymatic activity due to a decrease in intracellular cAMP concentration. Mutation of PDE family proteins causes the loss of enzymatic activity, which leads to the loss of intracellular cAMP degradation, an increase in intracellular cAMP concentration, and an increase in PKA activity. It has been reported that PDE8B is predominantly expressed in the adrenal glands and other steroid hormone-secreting organs. H305P decreases the enzymatic activity of PDE8B and increases the concentration of intracellular cAMP $[9,11]$. PDE11A, D609N, and M878V are mutations that decrease the enzymatic activity of PDE11A [9,12], similar to PDE8B mutations, and increase the concentration of intracellular CAMP. Due to the increased cAMP, PKA activity is subsequently increased, resulting in increased expression of CYP11B1, leading to hypersecretion of cortisol.

Mutations in the guanine nucleotide-binding protein subunit alpha (GNAS) gene, a G-protein alpha-subunit associated with MC2R, have also been reported in CPA. GNAS mutations activate cAMP-PKA signaling, which in turn enhances the expression of the downstream CYP11B1 gene [63]. The promoter region of the CYP11B1 gene contains transcription factor binding sequences such as Ad4, Ad5, and Ad1 [66]. Ad4 binds SF-1, while Ad5 binds orphan nuclear receptors such as those in the NR4A family and COUP-TF. In addition, Ad1 binds cAMP-PKA-responsive transcription factors such as CREB and CREM. CREB and CREM are thought to be important in CPA, where genetic mutations in cAMP-PKA signaling factors are common. Previous in vitro studies have shown that the Ad1 region plays a central role in transcriptional activation when cAMP-PKA signaling is activated, and CREB and CREM are considered the most important transcription factors in CPA. The CREB transcription factor-activating complex is composed mainly of HATs, such as p300 [67,68] and CREB-binding protein (CBP) [69] (Figure 7). However, there are no reports on the analysis of the CREB transcription factor complex in the adrenal gland, which is an important issue to be addressed in the future. The interaction of CREB with $\beta$-catenin and glucocorticoid receptors (GR) has been reported in other organs [70], which may provide interesting results.

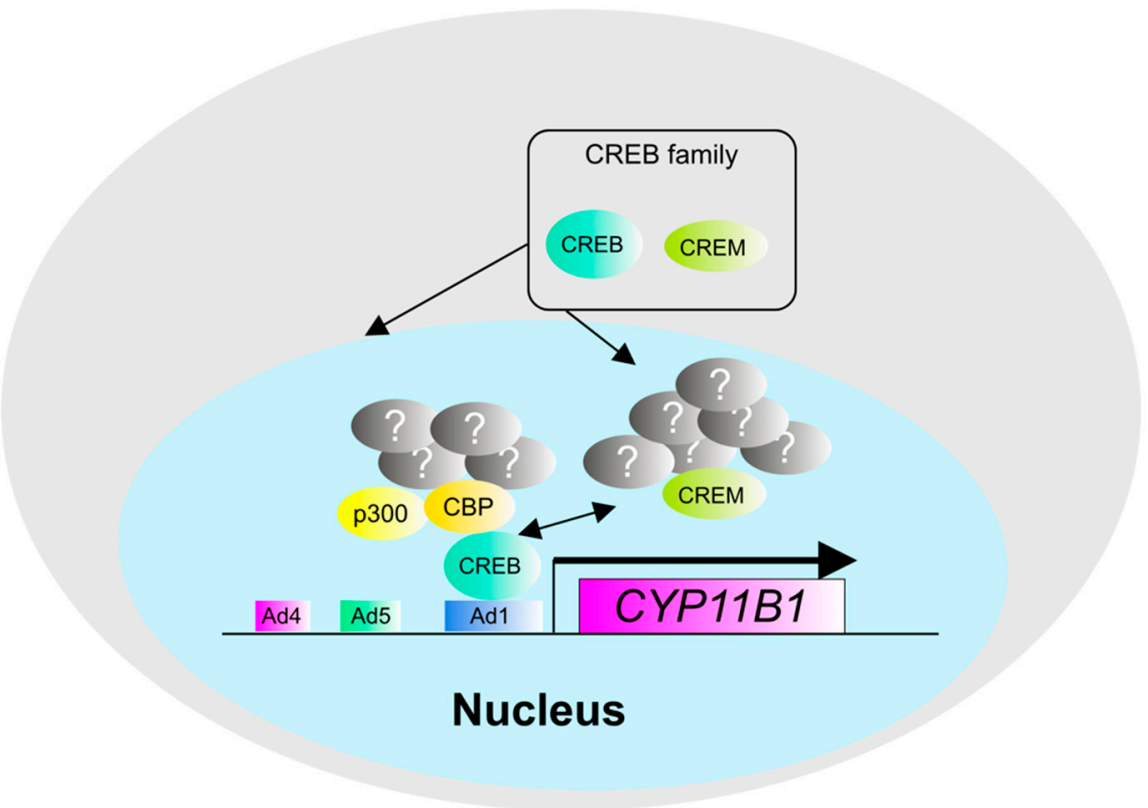

Figure 7. Transcriptional regulation of the CYP11B1 gene by the CREB family. The CREB family, including CREB and CREM, is involved in the regulation of gene expression of CYP11B1, a cortisol synthase. CREB has been identified as a component of the transcription factor complex with p300 and $\mathrm{CBP}$, but the other components are still unknown. 


\section{The Pathogenesis and Molecular Mechanisms in Adrenocortical Carcinoma (ACC)}

ACC is a malignant tumor arising from the adrenal cortex. The frequency of ACC is relatively low (approximately 1-2 per million), but its prognosis is poor or dismal due to its rapid clinical growth and progression. There are two types of ACCs: functional tumors that are based on the presence of hormone excess and nonfunctional tumors that do not secrete hormones.

Genetic mutations in adrenocortical malignancies have been detected in tumor suppressor genes such as TP53 and RB1 [17,71,72], mutations in Wnt- $\beta$-catenin system genes such as ZNRF3 and CTNNB1 [17,21,71], mutations in cell cycle-related genes such as $C D K N 2 A$ [17], and mutations in epigenomic and chromatin remodeling regulators such as DAXX, MED12, and MEN1 [17,71]. In addition, IGF2 (insulin-like growth factor 2), PRKAR1A, RPL22 (ribosomal protein L22), CCNE1 (cyclin E1), CDK4 (cyclin dependent kinase 4), TERT (telomerase reverse transcriptase), and TERF2 (telomeric repeat binding factor 2) have also been reported as genetic mutations in ACC [20].

Mutations in tumor suppressor genes are also frequently reported in cancers of other organs, and they play important roles in the pathogenesis of ACC.

TP53 mutations in ACC are nonsense or frameshift mutations that cause a loss of TP53 function [20]. TP53 gene is also known to be the causative gene of Li-Fraumeni syndrome. TP53 encodes p53 protein. The p53 protein is constantly degraded and accumulates in the cells when it detects DNA damage and suppresses cell growth [73]. The deletion of p53 leads to uncontrolled cell proliferation, which in turn leads to the growth of carcinoma cells. RB1 is a tumor suppressor gene detected in retinoblastoma, and RB protein binds to the transcription factor E2F and inhibits its transcriptional activity, thereby suppressing cell growth [74]. In ACC, RB has been reported to be functionally suppressive, suggesting that the RB-mediated cell growth suppression mechanism is disrupted $[17,18]$.

Mutations in the Wnt- $\beta$-catenin system, an important intracellular signal for cell proliferation, are also important. $\beta$-catenin is a transcription factor that is constantly degraded, and its degradation mechanism is regulated by the phosphorylation of $\beta$-catenin [75]. Wnt proteins bind to the Frizzled receptor and couple with the LRP receptor, inactivating GSK3B, which is a phosphatase of $\beta$-catenin, allowing $\beta$-catenin protein to be spared from degradation $[75,76]$. As a result, $\beta$-catenin accumulates in the cells and contributes to the expression of downstream genes. Of note, the CTNNB1 mutation was frequently detected in ACC, suggesting its possible contribution to tumor growth or progression. $\beta$-catenin is a transcription factor, and its activation depends not only on the accumulation of $\beta$-catenin in the nucleus by post-translational modification but also on the effect of transcription factor complexes. Therefore, it is expected that the epigenomic factors that construct the transcription factor complex will be elucidated in the future, in order to be able to develop drugs that specifically target it.

ZNRF3 is a cell surface ubiquitin ligase that regulates Wnt- $\beta$-catenin signaling by ubiquitinating and degrading the Wnt protein receptors Frizzled and LRP6 [77]. When ZNRF3 loses its activity due to mutation, Wnt- $\beta$-catenin signaling is not regulated and $\beta$-catenin activity is increased $[17,71]$ (Figure 8 ).

Additionally, mutations in epigenetic regulators may increase the transcriptional activity of $\beta$-catenin, which may be involved in tumorigenesis.

MED12 (mediator of RNA polymerase II transcription subunit 12 homolog) is a known factor that interacts with RNA polymerase. MED12 is involved in the activity of $\beta$ catenin, and its mutation has been reported to increase the activity of Akt and decrease the activity of GSK3B, an upstream regulator of $\beta$-catenin, resulting in increased transcriptional activity of $\beta$-catenin [78-80]. This suggests that MED12 mutations contribute to the growth of malignant tumors $[17,79,80]$. However, the details of molecular regulation between mutations and growth, as well as changes in chromatin status and cancer caused by MED12 mutations, remain unclear, and future studies are expected (Figure 8). 

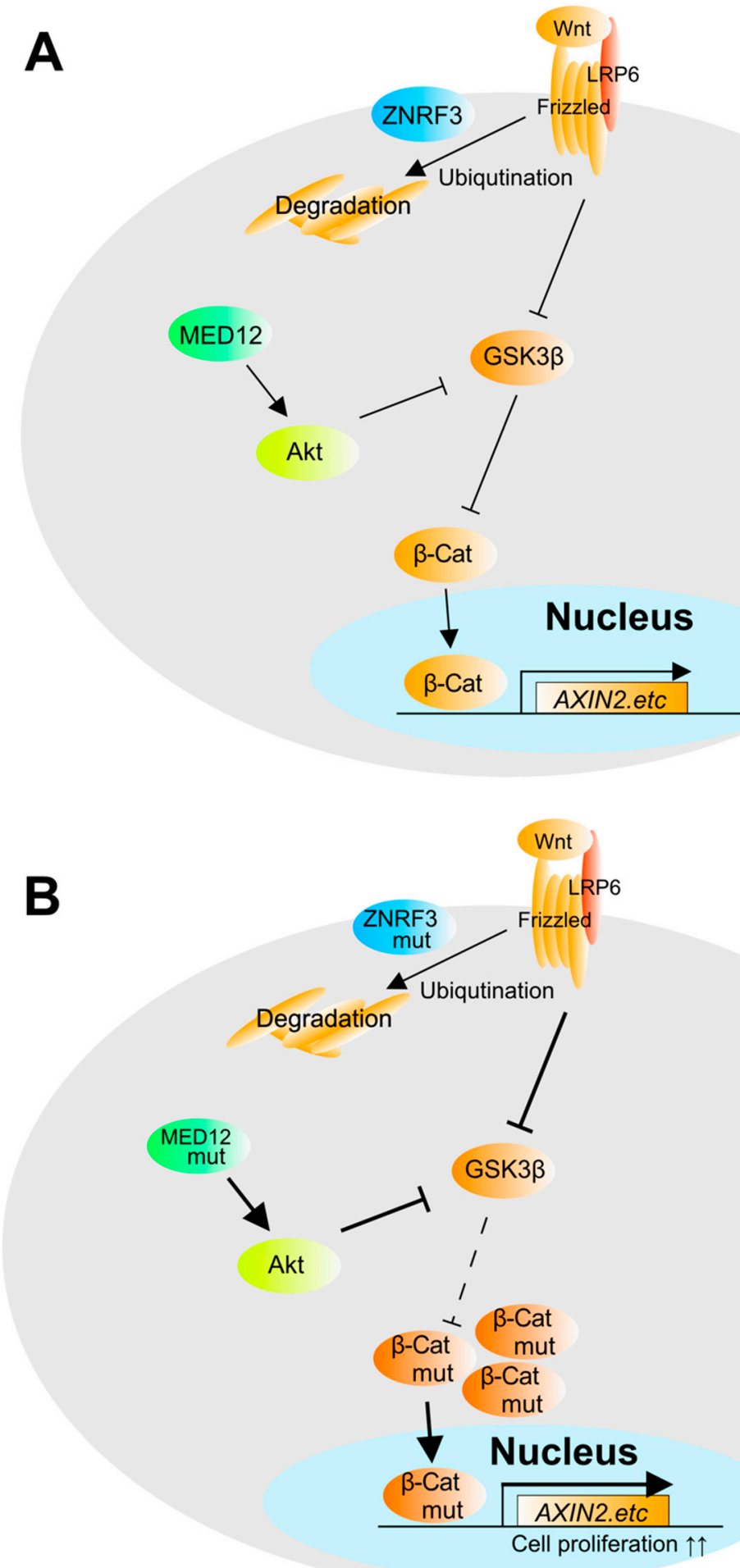

Figure 8. Genetic mutations in adrenocortical carcinoma. In adrenocortical carcinoma, mutations in the $\beta$-catenin system have been reported. (A) $\beta$-catenin pathway in non-ACC. (B) $\beta$-catenin pathway in ACC. AXIN2 is $\beta$-catenin regulator via GSK3B. ZNRF3 is a ubiquitin ligase that regulates the degradation of Frizzled and LRP6. Mutation of MED12 enhances the activation of Akt and further enhances the transcriptional activity of $\beta$-catenin.

MEN1 encodes Menin, is a tumor suppressor gene and a causative gene of multiple endocrine neoplasia type 1 (MEN1). MEN1 acts as a transcriptional repressor in the epigenome, forming protein-protein interactions with various transcription factors and 
repressing their transcriptional activity. It has been reported that MEN1 also binds to $\beta$-catenin and affects its transcriptional activity, while $\beta$-catenin has been reported to activate transcription [81,82]. Mutations in MEN1 have been implicated in the pathogenesis of MEN1, and Menin promotes the expression of p27 mutations in MEN1, which have been implicated in the pathogenesis of MEN1. However, the mechanism by which Menin promotes p27 expression and inhibits cell proliferation is thought to be disrupted by genetic mutations [82]. The same is thought to be true in adrenal cancers.

$D A X X$, a chromatin remodeling factor, affects histone $\mathrm{H} 3.3$ and promotes telomere elongation. It also interacts with $\beta$-catenin and TCF4 to increase its transcriptional activity [83]. Mutations of DAXX in ACC are often reported to be deletion type mutations, and their relevance to proliferation is currently unclear.

IGF2 is a key factor in adrenal development, and increased gene expression has been reported in ACC [84]. IGF2 has been reported to proliferate H295R cells [85], suggesting that it is an important factor in the proliferation of ACC. Recently, novel gene mutations have been investigated in RPL22, CCNE1, CDK4, TERT, and TERF2 in ACC using RNA sequencing [20]. CCNE1 and CDK4 are cell cycle regulating genes, which control cell proliferation, while TERT and TERF2 are telomere-related genes, which regulate cell senescence and immortality.

Additionally, ACC has been investigated using next-generation sequencing, and mutations in genes such as LRIG1, ZFPM1, CRIPAK, GARS, and ZNF517 have been discovered [16]. Although the correlation between adrenocortical cell tumorigenesis and cancer malignancy remains unclear, it is expected to be a topic for future research on genetic mutations in ACC.

As mentioned above, $\beta$-catenin, which plays a critical role in adrenal carcinoma, binds to the transcription factors TCF or LEF to form transcription factor complexes. p300 [86], CBP [87], and other HATs, and MLL1/2 [88] belonging to the lysine-specific methyltransferase (KMT) family of proteins, are representative components of $\beta$-catenin transcription factor complexes. However, the $\beta$-catenin transcription complex in the adrenal gland has not been studied in detail, and the analysis of organ-specific transcription factor complexes has not progressed.

\section{Conclusions}

In APA, the cause of PA, the upregulation of aldosterone synthesis genes by calcium signaling is a key cascade that enhances aldosterone secretion by activating transcription factors, mainly the NR4A family. In CPA, the activation of cAMP-responsive transcription factors such as CREB increases cortisol secretion by upregulating the gene expression of CYP11B1. The Wnt- $\beta$-catenin system is important in ACC, and the suppression of $\beta$-catenin transcriptional activity is important in future therapeutic development. Mutations of $\beta$-catenin have been reported in adenomas, but $\beta$-catenin is mainly involved in tumorigenesis, and in adenomas, it seems to promote steroid production as a secondary effect by affecting the NR4A family and CREB. In addition, the presence of transcription factor complexes is important for the activation of transcription factors, and future studies focusing on transcription factors and transcription factor complexes are warranted in APA, CPA, and ACC.

Funding: This research received no external funding.

Conflicts of Interest: The authors declare no conflict of interest. 


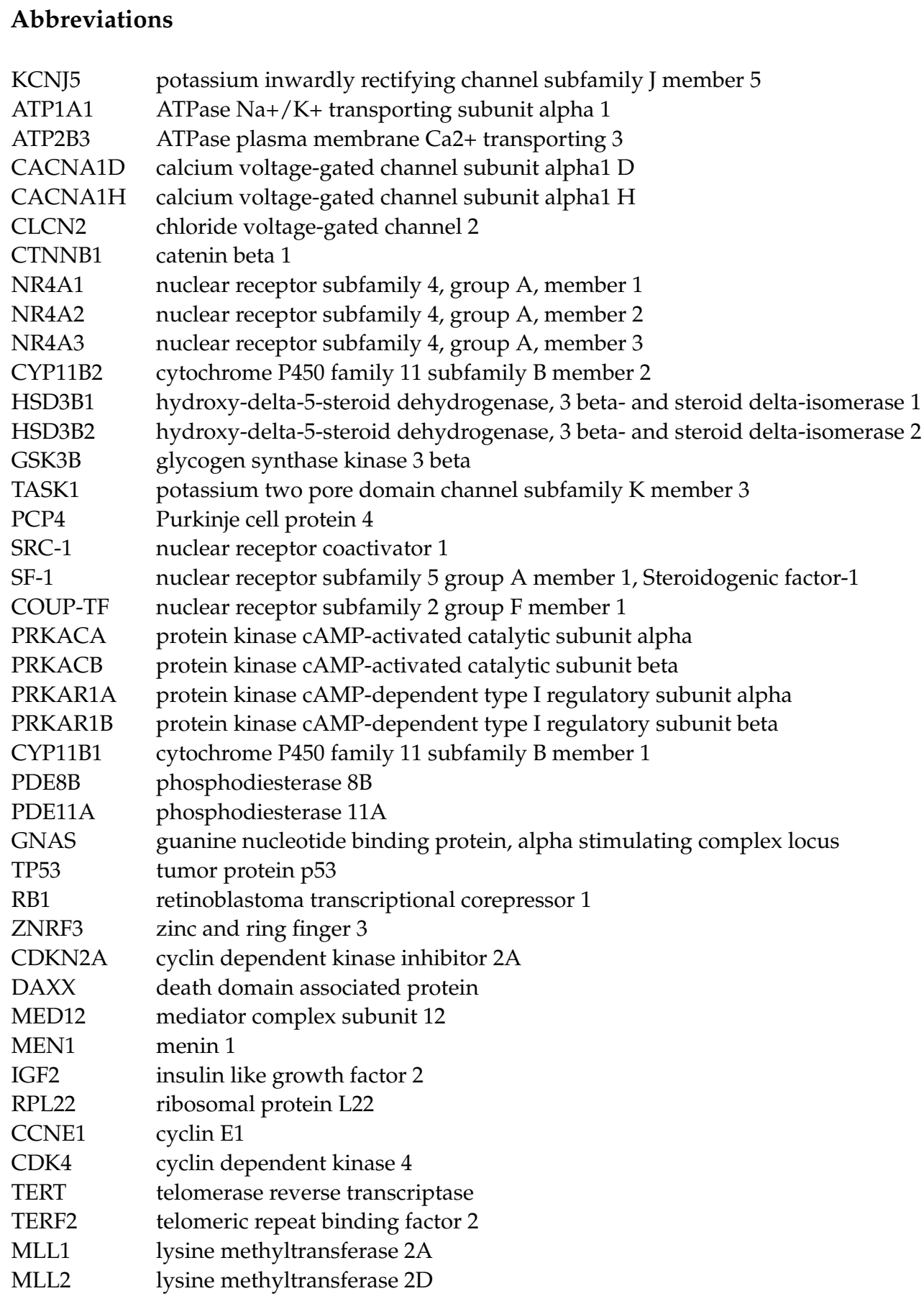

\section{References}

1. Nanba, K.; Blinder, A.R.; Rege, J.; Hattangady, N.G.; Else, T.; Liu, C.-J.; Tomlins, S.A.; Vats, P.; Kumar-Sinha, C.; Giordano, T.J.; et al. Somatic CACNA1H Mutation as a Cause of Aldosterone-Producing Adenoma. Hypertens 2020, 75, 645-649. [CrossRef]

2. Williams, T.A.; Monticone, S.; Schack, V.R.; Stindl, J.; Burrello, J.; Buffolo, F.; Annaratone, L.; Castellano, I.; Beuschlein, F.; Reincke, M.; et al. Somatic ATP1A1, ATP2B3, and KCNJ5 mutations in aldosterone-producing adenomas. Hypertens 2014, 63, 188-195. [CrossRef]

3. Scholl, U.I.; Goh, G.; Stölting, G.; De Oliveira, R.C.; Choi, M.; Overton, J.D.; Fonseca, A.L.; Korah, R.; Starker, L.F.; Kunstman, J.; et al. Somatic and germline CACNA1D calcium channel mutations in aldosterone-producing adenomas and primary aldosteronism. Nat. Genet. 2013, 45, 1050-1054. [CrossRef] [PubMed]

4. Dutta, R.K.; Arnesen, T.; Heie, A.; Walz, M.; Alesina, P.; Söderkvist, P.; Gimm, O. A somatic mutation in CLCN2 identified in a sporadic aldosterone-producing adenoma. Eur. J. Endocrinol. 2019, 181, K37-K41. [CrossRef]

5. $\quad$ Rege, J.; Nanba, K.; Blinder, A.R.; Plaska, S.; Udager, A.M.; Vats, P.; Kumar-Sinha, C.; Giordano, T.J.; Rainey, W.E.; Else, T. Identification of Somatic Mutations in CLCN2 in Aldosterone-Producing Adenomas. J. Endocr. Soc. 2020, 4, bvaa123. [CrossRef] 
6. $\quad$ Espiard, S.; Knape, M.J.; Bathon, K.; Assié, G.; Rizk-Rabin, M.; Faillot, S.; Luscap-Rondof, W.; Abid, D.; Guignat, L.; Calebiro, D.; et al. Activating PRKACB somatic mutation in cortisol-producing adenomas. JCI Insight. 2018, 3, e98296. [CrossRef]

7. Libé, R.; Mantovani, G.; Bondioni, S.; Lania, A.G.; Pedroni, C.; Beck-Peccoz, P.; Spada, A. Mutational Analysis of PRKAR1A and Gs $\alpha$ in Sporadic Adrenocortical Tumors. Exp. Clin. Endocrinol. Diabetes. 2005, 113, 248-251. [CrossRef]

8. Vincent-Dejean, C.; Cazabat, L.; Groussin, L.; Perlemoine, K.; Fumey, G.; Tissier, F.; Bertagna, X.; Bertherat, J. Identification of a clinically homogenous subgroup of benign cortisol-secreting adrenocortical tumors characterized by alterations of the protein kinase A (PKA) subunits and high PKA activity. Eur. J. Endocrinol. 2008, 158, 829-839. [CrossRef]

9. Leal, L.F.; Szarek, E.; Faucz, F.; Stratakis, C.A. Phosphodiesterase 8B and cyclic AMP signaling in the adrenal cortex. Endocrine 2015, 50, 27-31. [CrossRef]

10. Bimpaki, E.I.; Nesterova, M.; Stratakis, C.A. Abnormalities of cAMP signaling are present in adrenocortical lesions associated with ACTH-independent Cushing syndrome despite the absence of mutations in known genes. Eur. J. Endocrinol. 2009, 161, 153-161. [CrossRef]

11. Horvath, A.; Giatzakis, C.; Tsang, K.; Greene, E.; Osorio, P.; Boikos, S.; Libè, R.; Patronas, Y.; Robinson-White, A.; Remmers, E.; et al. A cAMP-specific phosphodiesterase (PDE8B) that is mutated in adrenal hyperplasia is expressed widely in human and mouse tissues: A novel PDE8B isoform in human adrenal cortex. Eur. J. Hum. Genet. 2008, 16, 1245-1253. [CrossRef]

12. Vezzosi, D.; Libe, R.; Baudry, C.; Rizk-Rabin, M.; Horvath, A.; Levy, I.; René-Corail, F.; Ragazzon, B.; Stratakis, C.A.; Vandecasteele, G.; et al. Phosphodiesterase 11A (PDE11A) gene defects in patients with acth-independent macronodular adrenal hyperplasia (AIMAH): Functional variants may contribute to genetic susceptibility of bilateral adrenal tumors. J. Clin. Endocrinol. Metab. 2012, 97, E2063-E2069. [CrossRef] [PubMed]

13. Roussel, H.W.; Vezzosi, D.; Rizk-Rabin, M.; Barreau, O.; Ragazzon, B.; René-Corail, F.; de Reynies, A.; Bertherat, J.; Assié, G. Identification of Gene Expression Profiles Associated with Cortisol Secretion in Adrenocortical Adenomas. J. Clin. Endocrinol. Metab. 2013, 98, E1109-E1121. [CrossRef]

14. Beuschlein, F.; Fassnacht, M.; Assié, G.; Calebiro, D.; Stratakis, C.A.; Osswald, A.; Ronchi, C.L.; Wieland, T.; Sbiera, S.; Faucz, F.R.; et al. Constitutive activation of PKA catalytic subunit in adrenal Cushing's syndrome. N. Engl. J. Med. 2014, 370, 1019-1028. [CrossRef] [PubMed]

15. Thiel, A.; Reis, A.-C.; Haase, M.; Goh, G.; Schott, M.; Willenberg, H.S.; Scholl, U.I. PRKACA mutations in cortisol-producing adenomas and adrenal hyperplasia: A single-center study of 60 cases. Eur. J. Endocrinol. 2015, 172, 677-685. [CrossRef] [PubMed]

16. Rahane, C.; Kutzner, A.; Heese, K. Establishing a human adrenocortical carcinoma (ACC)-specific gene mutation signature. Cancer Genet. 2019, 230, 1-12. [CrossRef]

17. Assié, G.; Letouzé, E.; Fassnacht, M.; Jouinot, A.; Luscap, W.; Barreau, O.; Omeiri, H.; Rodriguez, S.; Perlemoine, K.; René-Corail, F.; et al. Integrated genomic characterization of adrenocortical carcinoma. Nat. Genet. 2014, 46, 607-612. [CrossRef]

18. Crona, J.; Beuschlein, F. Adrenocortical carcinoma-Towards genomics guided clinical care. Nat. Rev. Endocrinol. 2019, 15, 548-560. [CrossRef]

19. Duan, K.; Hernandez, K.G.; Mete, O. Clinicopathological correlates of adrenal Cushing's syndrome. J. Clin. Pathol. 2015, 68, 175-186. [CrossRef]

20. Zheng, S.; Cherniack, A.D.; Dewal, N.; Moffitt, R.A.; Danilova, L.; Murray, B.A.; Lerario, A.M.; Else, T.; Knijnenburg, T.A.; Ciriello, G.; et al. Comprehensive Pan-Genomic Characterization of Adrenocortical Carcinoma. Cancer Cell 2016, 29, 723-736. [CrossRef]

21. Pinto, E.M.; Chen, X.; Easton, J.; Finkelstein, D.; Liu, Z.; Pounds, S.; Rodriguez-Galindo, C.; Lund, T.C.; Mardis, E.R.; Wilson, R.K.; et al. Genomic landscape of paediatric adrenocortical tumours. Nat. Commun. 2015, 6, 6302. [CrossRef] [PubMed]

22. Azizan, E.A.B.; Poulsen, H.; Tuluc, P.; Zhou, J.; Clausen, M.V.; Lieb, A.; Maniero, C.; Garg, S.; Bochukova, E.G.; Zhao, W.; et al. Somatic mutations in ATP1A1 and CACNA1D underlie a common subtype of adrenal hypertension. Nat. Genet. 2013, 45, 1055-1060. [CrossRef]

23. Tan, G.C.; Negro, G.; Pinggera, A.; Tizen Laim, N.M.S.; Mohamed Rose, I.; Ceral, J.; Ryska, A.; Chin, L.K.; Kamaruddin, N.A.; Mohd Mokhtar, N.; et al. Aldosterone-Producing Adenomas: Histopathology-Genotype Correlation and Identification of a Novel CACNA1D Mutation. Hypertens 2017, 70, 129-136. [CrossRef]

24. Byrd, J.B.; Turcu, A.F.; Auchus, R.J. Primary Aldosteronism. Circulation 2018, 138, 823-835. [CrossRef] [PubMed]

25. Fernandes-Rosa, F.L.; Daniil, G.; Orozco, I.J.; Göppner, C.; El Zein, R.; Jain, V.; Boulkroun, S.; Jeunemaitre, X.; Amar, L.; Lefebvre, H.; et al. A gain-of-function mutation in the CLCN2 chloride channel gene causes primary aldosteronism. Nat. Genet. 2018, 50, 355-361. [CrossRef]

26. Zennaro, M.-C.; Boulkroun, S.; Fernandes-Rosa, F. Genetic Causes of Functional Adrenocortical Adenomas. Endocr. Rev. 2017, 38, 516-537. [CrossRef]

27. Choi, M.; Scholl, U.I.; Yue, P.; Björklund, P.; Zhao, B.; Nelson-Williams, C.; Ji, W.; Cho, Y.; Patel, A.; Men, C.J.; et al. Lifton, $\mathrm{K}+$ channel mutations in adrenal aldosterone-producing adenomas and hereditary hypertension. Science 2011, 331, 768-772. [CrossRef]

28. Bassett, M.H.; Suzuki, T.; Sasano, H.; White, P.C.; Rainey, W.E. The Orphan Nuclear Receptors NURR1 and NGFIB Regulate Adrenal Aldosterone Production. Mol. Endocrinol. 2004, 18, 279-290. [CrossRef]

29. Romero, D.G.; Rilli, S.; Plonczynski, M.W.; Yanes, L.L.; Zhou, M.Y.; Gomez-Sanchez, E.P.; Gomez-Sanchez, C.E. Adrenal transcription regulatory genes modulated by angiotensin II and their role in steroidogenesis. Physiol. Genom. 2007, 30, 26-34. [CrossRef] 
30. Zennaro, M.-C.; Jeunemaitre, X.; Boulkroun, S. Integrating genetics and genomics in primary aldosteronism. Hypertens 2012, 60, 580-588. [CrossRef]

31. Hattangady, N.G.; Karashima, S.; Yuan, L.; Ponce-Balbuena, D.; Jalife, J.; Gomez-Sanchez, C.E.; Auchus, R.J.; Rainey, W.E.; Else, T. Else, Mutated KCNJ5 activates the acute and chronic regulatory steps in aldosterone production. J. Mol. Endocrinol. 2016, 57, 1-11. [CrossRef]

32. Nakamura, Y.; Felizola, S.J.A.; Satoh, F.; Konosu-Fukaya, S.; Sasano, H. Dissecting the molecular pathways of primary aldosteronism. Pathol. Int. 2014, 64, 482-489. [CrossRef]

33. Beuschlein, F.; Boulkroun, S.; Osswald, A.; Wieland, T.; Nielsen, H.N.; Lichtenauer, U.D.; Penton, D.; Schack, V.R.; Amar, L.; Fischer, E.; et al. Somatic mutations in ATP1A1 and ATP2B3 lead to aldosterone-producing adenomas and secondary hypertension. Nat. Genet. 2013, 45, 440-444. [CrossRef]

34. Stindl, J.; Tauber, P.; Sterner, C.; Tegtmeier, I.; Warth, R.; Bandulik, S. Pathogenesis of Adrenal Aldosterone-Producing Adenomas Carrying Mutations of the $\mathrm{Na}(+) / \mathrm{K}(+)$-ATPase. Endocrinology 2015, 156, 4582-4591. [CrossRef]

35. Kitamoto, T.; Suematsu, S.; Yamazaki, Y.; Nakamura, Y.; Sasano, H.; Matsuzawa, Y.; Saito, J.; Omura, M.; Nishikawa, T. Clinical and Steroidogenic Characteristics of Aldosterone-Producing Adenomas with ATPase or CACNA1D Gene Mutations. J. Clin. Endocrinol. Metab. 2016, 101, 494-503. [CrossRef]

36. Pinggera, A.; Negro, G.; Tuluc, P.; Brown, M.J.; Lieb, A.; Striessnig, J. Gating defects of disease-causing de novo mutations in Ca $\mathrm{v}$ $1.3 \mathrm{Ca}^{2+}$ channels. Channels 2018, 12, 388-402. [CrossRef]

37. Ortner, N.J.; Kaserer, T.; Copeland, J.N.; Striessnig, J. De novo CACAN1D Ca2+ channelopathies: Clinical phenotypes and molecular mechanism. Pflügers Arch. Eur. J. Physiol. 2020, 472, 755-773. [CrossRef]

38. Scholl, U.I.; Stölting, G.; Schewe, J.; Thiel, A.; Tan, H.; Nelson-Williams, C.; Vichot, A.A.; Jin, S.C.; Loring, E.; Untiet, V.; et al. CLCN2 chloride channel mutations in familial hyperaldosteronism type II. Nat. Genet. 2018, 50, 349-354. [CrossRef]

39. Teo, A.E.D.; Garg, S.; Haris Shaikh, L.; Zhou, J.; Karet, F.F.E.; Gurnell, M.; Happerfield, L.; Marker, A.; Bienz, M.; Azizan, E.A.B.; et al. Pregnancy, Primary Aldosteronism, and Adrenal CTNNB1 Mutations. N. Engl. J. Med. 2015, 373, 1429-1436. [CrossRef]

40. Wang, J.-J.; Peng, K.-Y.; Wu, V.-C.; Tseng, F.-Y.; Wu, K.-D. CTNNB1 Mutation in Aldosterone Producing Adenoma. Endocrinol. Metab. 2017, 32, 332. [CrossRef]

41. Oki, K.; Gomez-Sanchez, C.E. The landscape of molecular mechanism for aldosterone production in aldosterone-producing adenoma. Endocr. J. 2020, 67, 989-995. [CrossRef]

42. Heitzmann, D.; Derand, R.; Jungbauer, S.; Bandulik, S.; Sterner, C.; Schweda, F.; El Wakil, A.; Lalli, E.; Guy, N.; Mengual, R.; et al. Invalidation of TASK1 potassium channels disrupts adrenal gland zonation and mineralocorticoid homeostasis. EMBO J. 2008, 27, 179-187. [CrossRef]

43. Felizola, S.J.A.; Nakamura, Y.; Ono, Y.; Kitamura, K.; Kikuchi, K.; Onodera, Y.; Ise, K.; Takase, K.; Sugawara, A.; Hattangady, N.; et al. PCP4: A regulator of aldosterone synthesis in human adrenocortical tissues. J. Mol. Endocrinol. 2014, 52, 159-167. [CrossRef]

44. Kobuke, K.; Oki, K.; Gomez-Sanchez, C.E.; Gomez-Sanchez, E.P.; Ohno, H.; Itcho, K.; Yoshii, Y.; Yoneda, M.; Hattori, N. Calneuron 1 Increased $\mathrm{Ca} 2+$ in the Endoplasmic Reticulum and Aldosterone Production in Aldosterone-Producing Adenoma. Hypertens 2018, 71, 125-133. [CrossRef]

45. Konosu-Fukaya, S.; Nakamura, Y.; Satoh, F.; Felizola, S.J.; Maekawa, T.; Ono, Y.; Morimoto, R.; Ise, K.; Takeda, K.-I.; Katsu, K.; et al. 3ß-Hydroxysteroid dehydrogenase isoforms in human aldosterone-producing adenoma. Mol. Cell. Endocrinol. 2015, 408, 205-212. [CrossRef]

46. Hattangady, N.G.; Olala, L.O.; Bollag, W.B.; Rainey, W.E. Acute and chronic regulation of aldosterone production. Mol. Cell. Endocrinol. 2012, 350, 151-162. [CrossRef]

47. Bassett, M.H.; White, P.C.; E Rainey, W. The regulation of aldosterone synthase expression. Mol. Cell. Endocrinol. 2004, 217, 67-74. [CrossRef]

48. Shimada, H.; Kogure, N.; Noro, E.; Kudo, M.; Sugawara, K.; Sato, I.; Shimizu, K.; Kobayashi, M.; Suzuki, D.; Parvin, R.; et al. High glucose stimulates expression of aldosterone synthase (CYP11B2) and secretion of aldosterone in human adrenal cells. FEBS Open Bio 2017, 7, 1410-1421. [CrossRef]

49. Wansa, K.D.S.A.; Harris, J.; Muscat, G. The activation function-1 domain of Nur77/NR4A1 mediates trans-activation, cell specificity, and coactivator recruitment. J. Biol. Chem. 2002, 277, 33001-33011. [CrossRef]

50. Kelly, S.N.; McKenna, T.J.; Young, L.S. Coregulatory protein-orphan nuclear receptor interactions in the human adrenal cortex. J. Endocrinol. 2005, 186, 33-42. [CrossRef]

51. Holla, V.R.; Wu, H.; Shi, Q.; Menter, D.G.; DuBois, R.N. Nuclear orphan receptor NR4A2 modulates fatty acid oxidation pathways in colorectal cancer. J. Biol. Chem. 2011, 286, 30003-30009. [CrossRef] [PubMed]

52. Noro, E.; Yokoyama, A.; Kobayashi, M.; Shimada, H.; Suzuki, S.; Hosokawa, M.; Takehara, T.; Parvin, R.; Igarashi, K.; Sugawara, A.; et al. Endogenous Purification of NR4A2 (Nurr1) Identified Poly (ADP-Ribose) Polymerase 1 as a Prime Coregulator in Human Adrenocortical H295R Cells. Int. J. Mol. Sci. 2018, 19, 1406. [CrossRef] [PubMed]

53. Hu, D.; Ouyang, J.; Wu, Z.; Shi, T.; Wang, B.; Ma, X.; Li, H.; Wang, S.; Zhang, X. Elementary studies on elevated steroidogenic factor-1 expression in aldosterone-producing adenoma. Urol. Oncol. Semin. Orig. Investig. 2012, 30, 457-462. [CrossRef] [PubMed]

54. Baba, T.; Otake, H.; Sato, T.; Miyabayashi, K.; Shishido, Y.; Wang, C.-Y.; Shima, Y.; Kimura, H.; Yagi, M.; Ishihara, Y.; et al. Glycolytic genes are targets of the nuclear receptor Ad4BP/SF-1. Nat. Commun. 2014, 5, 3634. [CrossRef] 
55. Baba, T.; Otake, H.; Inoue, M.; Sato, T.; Ishihara, Y.; Moon, J.-Y.; Tsuchiya, M.; Miyabayashi, K.; Ogawa, H.; Shima, Y.; et al. Ad4BP/SF-1 regulates cholesterol synthesis to boost the production of steroids. Commun. Biol. 2018, 1, 18. [CrossRef] [PubMed]

56. Shibata, H.; Kurihara, I.; Kobayashi, S.; Yokota, K.; Suda, N.; Saito, I.; Saruta, T. Regulation of differential COUP-TF-coregulator interactions in adrenal cortical steroidogenesis. J. Steroid Biochem. Mol. Biol. 2003, 85, 449-456. [CrossRef]

57. Ota, T.; Doi, M.; Yamazaki, F.; Yarimizu, D.; Okada, K.; Murai, I.; Hayashi, H.; Kunisue, S.; Nakagawa, Y.; Okamura, H. Angiotensin II triggers expression of the adrenal gland zona glomerulosa-specific $3 \beta$-hydroxysteroid dehydrogenase isoenzyme through de novo protein synthesis of the orphan nuclear receptors NGFIB and NURR1. Mol. Cell. Biol. 2014, 34, 3880-3894. [CrossRef]

58. Scholl, U.I.; Abriola, L.; Zhang, C.; Reimer, E.N.; Plummer, M.; Kazmierczak, B.I.; Zhang, J.; Hoyer, D.; Merkel, J.S.; Wang, W.; et al. Macrolides selectively inhibit mutant KCNJ5 potassium channels that cause aldosterone-producing adenoma. J. Clin. Investig. 2017, 127, 2739-2750. [CrossRef]

59. Ito, R.; Sato, I.; Tsujita, T.; Yokoyama, A.; Sugawara, A. A ubiquitin-proteasome inhibitor bortezomib suppresses the expression of CYP11B2, a key enzyme of aldosterone synthesis. Biochem. Biophys. Res. Commun. 2017, 489, 21-28. [CrossRef]

60. Uruno, A.; Matsuda, K.; Noguchi, N.; Yoshikawa, T.; Kudo, M.; Satoh, F.; Rainey, W.E.; Hui, X.G.; Akahira, J.I.; Nakamura, Y.; et al. Peroxisome proliferator-activated receptor- $\gamma$ suppresses CYP11B2 expression and aldosterone production. J. Mol. Endocrinol. 2011, 46, 37-49. [CrossRef]

61. Suzuki, D.; Saito-Hakoda, A.; Ito, R.; Shimizu, K.; Parvin, R.; Shimada, H.; Noro, E.; Suzuki, S.; Fujiwara, I.; Kagechika, H.; et al. Suppressive effects of RXR agonist PA024 on adrenal CYP11B2 expression, aldosterone secretion and blood pressure. PLoS ONE 2017, 12, e0181055. [CrossRef] [PubMed]

62. Sato, Y.; Maekawa, S.; Ishii, R.; Sanada, M.; Morikawa, T.; Shiraishi, Y.; Yoshida, K.; Nagata, Y.; Sato-Otsubo, A.; Yoshizato, T.; et al. Recurrent somatic mutations underlie corticotropin-independent Cushing's syndrome. Science 2014, 344, 917-920. [CrossRef]

63. Fragoso, M.C.B.V.; Domenice, S.; Latronico, A.C.; Martin, R.M.; Pereira, M.A.A.M.; Zerbini, C.N.; Lucon, A.M.; Mendonca, B.B. Cushing's Syndrome Secondary to Adrenocorticotropin-Independent Macronodular Adrenocortical Hyperplasia due to Activating Mutations of GNAS1 Gene. J. Clin. Endocrinol. Metab. 2003, 88, 2147-2151. [CrossRef]

64. Di Dalmazi, G.; Altieri, B.; Scholz, C.-J.; Sbiera, S.; Luconi, M.; Waldman, J.; Kastelan, D.; Ceccato, F.; Chiodini, I.; Arnaldi, G.; et al. RNA Sequencing and Somatic Mutation Status of Adrenocortical Tumors: Novel Pathogenetic Insights. J. Clin. Endocrinol. Metab. 2020, 105, e4459-e4473. [CrossRef]

65. Drougat, L.; Settas, N.; Ronchi, C.L.; Bathon, K.; Calebiro, D.; Maria, A.G.; Haydar, S.; Voutetakis, A.; London, E.; Faucz, F.R.; et al. Genomic and sequence variants of protein kinase A regulatory subunit type $1 \beta$ (PRKAR1B) in patients with adrenocortical disease and Cushing syndrome. Genet. Med. 2021, 23, 174. [CrossRef]

66. Cheng, L.-C.; Pai, T.-W.; Li, L.-A. Regulation of human CYP11B1 and CYP11B2 promoters by transposable elements and conserved cis elements. Steroids 2012, 77, 100-109. [CrossRef]

67. Tung, W.-H.; Hsieh, H.-L.; Lee, I.-T.; Yang, C.-M. Enterovirus 71 modulates a COX-2/PGE2/cAMP-dependent viral replication in human neuroblastoma cells: Role of the c-Src/EGFR/p42/p44 MAPK/CREB signaling pathway. J. Cell. Biochem. 2011, 112, 559-570. [CrossRef]

68. Tong, Q.; Weaver, M.R.; Kosmacek, E.A.; O'Connor, B.P.; Harmacek, L.; Venkataraman, S.; Oberley-Deegan, R.E. MnTE-2-PyP reduces prostate cancer growth and metastasis by suppressing p300 activity and p300/HIF-1/CREB binding to the promoter region of the PAI-1 gene. Free Radic. Biol. Med. 2016, 94, 185-194. [CrossRef]

69. Shi, Y.; Venkataraman, S.L.; Dodson, G.E.; Mabb, A.M.; LeBlanc, S.; Tibbetts, R.S. Direct regulation of CREB transcriptional activity by ATM in response to genotoxic stress. Proc. Natl. Acad. Sci. USA 2004, 101, 5898-5903. [CrossRef]

70. Guo, C.; Li, J.; Myatt, L.; Zhu, X.; Sun, K. Induction of Galphas contributes to the paradoxical stimulation of cytosolic phospholipase A2alpha expression by cortisol in human amnion fibroblasts. Mol. Endocrinol. 2010, 24, 1052-1061. [CrossRef]

71. Kamilaris, C.D.C.; Hannah-Shmouni, F.; Stratakis, C.A. Adrenocortical tumorigenesis: Lessons from genetics. Best Pract. Res. Clin. Endocrinol. Metab. 2020, 34, 101428. [CrossRef]

72. Juhlin, C.C.; Goh, G.; Healy, J.; Fonseca, A.L.; Scholl, U.I.; Stenman, A.; Kunstman, J.; Brown, T.C.; Overton, J.D.; Mane, S.M.; et al Whole-Exome Sequencing Characterizes the Landscape of Somatic Mutations and Copy Number Alterations in Adrenocortical Carcinoma. J. Clin. Endocrinol. Metab. 2015, 100, E493-E502. [CrossRef]

73. Bieging, K.T.; Mello, S.S.; Attardi, L.D. Unravelling mechanisms of p53-mediated tumour suppression. Nat. Rev. Cancer. 2014, 14, 359-370. [CrossRef]

74. Harbour, J.W.; Dean, D.C. Rb function in cell-cycle regulation and apoptosis. Nat. Cell Biol. 2000, 2, E65-E67. [CrossRef]

75. Gao, C.; Xiao, G.; Hu, J. Regulation of Wnt/ $\beta$-catenin signaling by posttranslational modifications. Cell Biosci. $2014,4,13$. [CrossRef]

76. Shang, S.; Hua, F.; Hu, Z.-W. The regulation of $\beta$-catenin activity and function in cancer: Therapeutic opportunities. Oncotarget 2017, 8, 33972-33989. [CrossRef]

77. Tsukiyama, T.; Koo, B.; Hatakeyama, S. Post-translational Wnt receptor regulation: Is the fog slowly clearing? BioEssays 2021, 43, 2000297. [CrossRef]

78. Wang, H.; Shen, Q.; Ye, L.-H.; Ye, J. MED12 mutations in human diseases. Protein Cell 2013, 4, 643-646. [CrossRef] [PubMed]

79. El Andaloussi, A.; Al-Hendy, A.; Ismail, N.; Boyer, T.G.; Halder, S.K. Introduction of Somatic Mutation in MED12 Induces Wnt4/ $\beta$-Catenin and Disrupts Autophagy in Human Uterine Myometrial Cell. Reprod. Sci. 2020, 27, 823-832. [CrossRef] 
80. Al-Hendy, A.; Laknaur, A.; Diamond, M.P.; Ismail, N.; Boyer, T.G.; Halder, S.K. Silencing Med12 Gene Reduces Proliferation of Human Leiomyoma Cells Mediated via Wnt/ $\beta$-Catenin Signaling Pathway. Endocrinology 2017, 158, en.2016-1097. [CrossRef]

81. Chen, G.; A, J.; Wang, M.; Farley, S.; Lee, L.-Y.; Sawicki, M.P.; Lee, L.-Y.; Lee, L.-C. Menin promotes the Wnt signaling pathway in pancreatic endocrine cells. Mol. Cancer Res. 2008, 6, 1894-1907. [CrossRef]

82. Jiang, X.; Cao, Y.; Li, F.; Su, Y.; Li, Y.; Peng, Y.; Cheng, Y.; Zhang, C.; Wang, W.; Ning, G. Targeting $\beta$-catenin signaling for therapeutic intervention in MEN1-deficient pancreatic neuroendocrine tumours. Nat. Commun. 2014, 5, 5809. [CrossRef]

83. Huang, Y.-S.; Shih, H.-M. Daxx positively modulates $\beta$-catenin/TCF4-mediated transcriptional potential. Biochem. Biophys. Res. Commun. 2009, 386, 762-768. [CrossRef] [PubMed]

84. Baquedano, M.S.; Berensztein, E.; Saraco, N.; Dorn, G.V.; De Dávila, M.T.; A Rivarola, M.; Belgorosky, A. Expression of the IGF System in Human Adrenal Tissues from Early Infancy to Late Puberty: Implications for the Development of Adrenarche. Pediatr. Res. 2005, 58, 451-458. [CrossRef]

85. Pereira, S.; Monteiro, M.; Costa, M.M.; Moreira, Â.; Alves, M.G.; Oliveira, P.F.; Jarak, I.; Pignatelli, D. IGF2 role in adrenocortical carcinoma biology. Endocrine 2019, 66, 326-337. [CrossRef]

86. Sun, Y.; Kolligs, F.T.; Hottiger, M.; Mosavin, R.; Fearon, E.R.; Nabel, G.J. Regulation of beta -catenin transformation by the p300 transcriptional coactivator. Proc. Natl. Acad. Sci. USA 2000, 97, 12613-12618. [CrossRef]

87. Taurin, S.; Sandbo, N.; Qin, Y.; Browning, D.; Dulin, N.O. Phosphorylation of beta-catenin by cyclic AMP-dependent protein kinase. J. Biol. Chem. 2006, 281, 9971-9976. [CrossRef]

88. Sierra, J.; Yoshida, T.; Joazeiro, C.A.; Jones, K.A. The APC tumor suppressor counteracts beta-catenin activation and H3K4 methylation at Wnt target genes. Genes Dev. 2006, 20, 586-600. [CrossRef] 